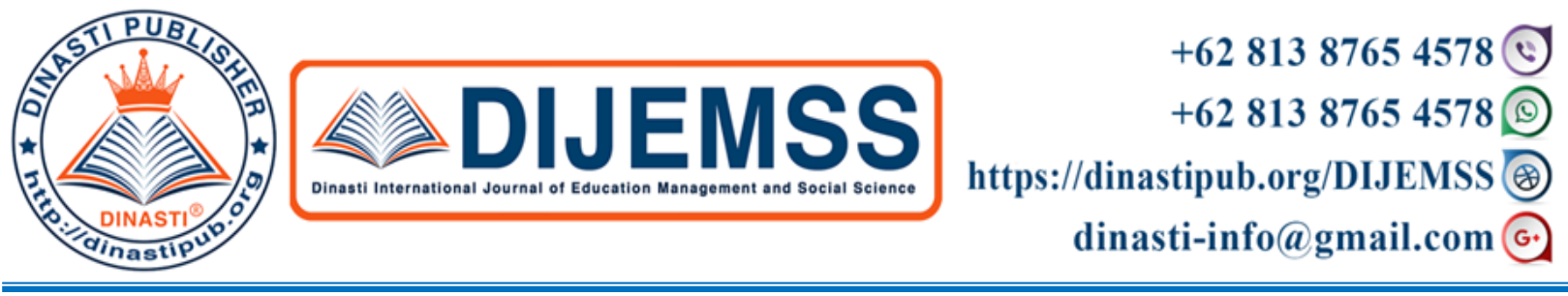

\title{
ANALYSIS OF OVERALL EQUIPMENT EFFECTIVENESS (OEE) ON EXCAVATOR HITACHI EX2500-6
}

\author{
Agus Daman $^{1}$ Dewi Nusraningrum ${ }^{2}$ \\ ${ }^{1}$ Agus Daman, Universitas Mercu Buana, Jakarta Indonesia \\ ${ }^{2}$ Dewi Nusraningrum, Universitas Mercu Buana, Jakarta Indonesia
}

\begin{tabular}{|c|c|}
\hline $\begin{array}{l}\text { ARTICLE INFORMATION } \\
\text { Received: } 16^{\text {th }} \text { June } 2020 \\
\text { Revised: } 25^{\text {th }} \text { July } 2020 \\
\text { Issued: } 22^{\text {th }} \text { August } 2020 \\
\text { Corresponding author: } \\
\text { First Author } \\
\text { E-mail: } \\
\text { agusdaman@ gmail.com }\end{array}$ & $\begin{array}{l}\text { Abstract: The Mining Industry is one of the pillars of national } \\
\text { economic development. In this industry, heavy equipment plays an } \\
\text { important role in the coal mining process in Indonesia. By using } \\
\text { heavy equipment must be well structured, so that the project can run } \\
\text { easily without any obstacles. This research aimed to evaluate the } \\
\text { cause of the low-value OEE of the Excavator Hitachi EX2500-6 of } \\
\text { EX157 and EX158 units and determine the way to repair so that the } \\
\text { equipment performance can be improved. This research uses } \\
\text { descriptive quantitative approach with value analysis methods } \\
\text { Overall Equipment Effectiveness (OEE). The result of OEE values } \\
\text { were analyzed using losses classification method so that the } \\
\text { occurrence of loss factors can be found and root cause analysis } \\
\text { performance using a causal diagram/fishbone diagram and then } \\
\text { make any improvement recommendations that can be done by using } \\
5 \text { W1H analysis. Based on the research results, the OEE values of } \\
\text { two excavators were calculated and were compared with the } \\
\text { benchmark values. The values of OEE were found to be } 84 \% \text { for } \\
\text { EX157 units and } 68 \% \text { for EX158 units. The low value of OEE on } \\
\text { EX158 caused by unscheduled maintenance time losses amounting } \\
\text { to } 1188.3 \text { hours. The high of time loss is influenced by trouble on } \\
\text { Machine Frame, Structure, Body, and Cab components amounted to } \\
60.9 \% \text {. The root causes of the losses derived from the availability of } \\
\text { external mechanics, the competence of mechanics, the availability of } \\
\text { spare parts, and the implementation of condition monitoring was not } \\
\text { optimal. While remedial steps can be taken by giving technical } \\
\text { training program for mechanics as maintenance practice } \\
\text { methodology. } \\
\text { Keywords: Total Productive Maintenance (TPM), Overall } \\
\text { Equipment Effectiveness (OEE), Excavator, Mining, Six Big Losses, } \\
\text { Fishbone Diagram, } 5 \text { W1H Analysis }\end{array}$ \\
\hline
\end{tabular}




\section{INTRODUCTION}

In the world of coal mining, heavy equipment may not be familiar to be heard and seen. These tools are used to support the mining process from opening a mine, making roads, excavating, pushing and transporting mining materials to the next process.

PT Petrosea, Tbk has several mining equipment / heavy equipment operating in the Tabang location such as excavators, trucks, graders, dozers, and cranes. This heavy equipment is used to assist the process of mining operations from the loading area to the disposal area. Excavator is the most important heavy equipment in mining operations because of its function as the main loading tool for coal (coal) and overburden (OB) material. PT Petrosea, Tbk currently has 3 types of excavator models operating that is in Tabang, Komatsu PC2000-8 are 3 units, Hitachi EX2500-6 are 2 units, and Libherr R9250 are 4 units.

The study was done by calculating of the actual value OEE for two excavators of Hitachi EX2500-6. The result of the calculation will be analyzed if the actual OEE value is found below the benchmark value. Researchers using secondary data within the company obtained during one year i.e., data for the year 2018 and will conduct a search of the factors cause by using the methods of the classification losses of excavator. Diagram analysis method using cause and effect/Fishbone diagrams and $5 \mathrm{~W} 1 \mathrm{H}$, this research will determine the alternative solutions of improvement that can be done so that the performance of the company's equipment that is changing for the better as well as on the other equipment.

\section{LITERATURE REVIEW}

\subsection{Total Productive Maintenance (TPM)}

Total Productive Maintenance was first defined in the 1970s by Seiichi Nakajima Japan Institute of Plant Maintenance, Nakajima (1989). Hamin et al (2017) said TPM is a philosophy that aims to maximize the effectiveness of facilities used in the industry, which is not only addressed to maintenance, but on all aspects of the operation and installation of production facilities, including increasing the motivation of people working in the company to take the part in equipment maintenance. TPM also has a goal that is without interruption of engine damage (zero breakdowns) and without product damage (zero defects). With this goal the level of use of tools will increase, costs and inventory will decrease, and subsequently employee productivity will increase.

Besides the purpose of TPM is to increase the effectiveness of the machine or equipment and maximize output (PQCDSM - Productivity, Quality, Cost, Delivery, Safety, Morale) by trying to avoid damage to the machine or equipment, losses due to reduced speed of the machine or equipment, damage to goods in the production process. By maximizing equipment, minimizing costs, and involving all members of the organization together in reducing are called (six big losses).

\subsection{OEE (Overall equipment effectiveness)}

Rozaq (2015) said OEE is a method that measures the level of effectiveness in the use of a machine / equipment or system by taking into account several points of view in the measurement 
process. In addition, OEE can also be defined as a metric that focuses on the effectiveness of an ongoing production operation. Elevli (2010) said OEE is a simple tool that will help manager to measure the effectiveness of their equipment. It takes the most common and important sources of productivity loss, which are called six big losses. These losses are quantified as availability, performance and quality in order to estimate OEE as given in equation (1).

$$
\mathrm{OEE}=\text { Availability } \mathrm{x} \text { Performance } \mathrm{x} \text { Quality }
$$

\subsection{OEE for Mining Equipment}

Elevli (2010) stated OEE applications in mining industry differ from manufacturing industry. Therefore, it is necessary to develop equipment's own classification framework for the losses, which should be associated with the components of availability, performance and quality. The necessary data classification to be collected will vary from equipment to equipment. In addition to that, it is more difficult to gather data for mining equipment due to following reasons:

a) Mining is a serial operation of drilling-blasting, loading, hauling and dumping. Therefore, the production of equipment used in each step depends on the production of previous equipment. That means utilization of each equipment affects the others.

b) The capacity of mining equipment is huge. Therefore the effect of utilization on total production is very high.

c) The physical environment under which mining equipment operates is less than ideal.

d) The operating environment of the mine is dynamic with many unknowns that can affect the equipment utilization drastically.

\subsection{Six Big Losses}

Haryanto and Susanty (2017) said in maintenance, there is a term Six Big Losses, which is a loss that must be avoided by every company. Six Big Losses are six losses that can reduce the level of effectiveness of a machine. Therefore, to increase machine / equipment productivity, it is necessary to analyze the productivity and efficiency of the engine at six big losses.

Saiful et. al (2014) said the purpose of this six big losses calculation is to find out the overall effectiveness value of the overall equipment effectiveness. There are six equipment losses that cause the low performance of the equipment as follows: (a). Equipment failure/breakdown losses, (b). Set up and adjustment losses, (c). Idling and minor stop losses, (d). Reduced speed losses, (e). Reduced yield, (f). Quality defect and rework.

\subsection{Fishbone Diagram (Ishikawa diagram)}

Goetsch (2019) said Fishbone diagram are used to identify and categorize the causes of problems. fishbone diagram developed by Dr. Kaoru Ishikawa in 1943 which is widely referred to as Ishikawa diagram or fishbone diagram, which is also a change of lines and symbols designed to represent the relationship between effects and causes.

Heston (2018) said Fishbone diagram illustrate lines and symbols that show the relationship between the effects and causes of a problem. The diagram is indeed used to determine the effects of a problem and then take corrective action. From this effect, several possible causes were 
sought. The cause of this problem can come from various main sources, such as work methods, materials, measurements, employees, environment, and so on.

Besterfield (2012) said Fishbone diagram is a picture that arranges lines and symbols intended to illustrate the important relationship between cause and effect.

\subsection{W1H}

Galiana (2019) said Otherwise known as the questioning method or the method of the Five Ws, $5 \mathrm{~W} 1 \mathrm{H}$ is an acronym in which every letter corresponds to a question: what, who, where, when, how and Why. This technique allows you to understand a situation, to discern a problem by analysing all the aspects. As outlined by Jean-Pierre Giraud, on the blog The big sales techniques: The 5W1H method allows you to discern the information needed to better understand, encompass, clarify, structure, frame a situation; as this way of thinking allows you to explore all the dimensions from different perspectives. This tool is very popular amongst journalists whilst also being used and applied to different contexts. It will help you ask the right questions, expand your enquiry and obtain the right information, which in turn helps you find the best solutions. This method allows you to guide all your team members and to gather all the factual elements needed for a complete and objective understanding.

\section{RESEARCH METHODS}

This research is quantitative research by doing calculations or analysis of performance calculated using OEE of each machine on two Excavators Hitachi EX2500-6 for knowing the problems and solutions of low-productivity equipment, this research also do descriptive exploratory analysis using the causal diagram. The population in this studies all Excavator Hitachi EX2500-6 two units. This research took two samples on the Excavator Hitachi EX25006.

Data on the availability and performance excavator derived from FMS (Fleet Management System) and maintenance operation reporting in units (Hour) except data on Quality derived from Bucket Fill Factor. To achieve the overall equipment effectiveness (OEE), then the first step that is the focus of major losses to eliminate (the classification losses on excavator), then the analysis of the Causal (Ishikawa diagram), and the making of the recommendation or proposed improvement measures made after the known results of the calculation of the Overall Equipment Effectiveness, six big losses and the result of the root of the problem using cause and effect analysis.

\section{RESULTS AND DISCUSSION}

\section{Result}

The various time losses (average) measured for excavator EX157 and EX158 are presented in Table 1. The values of three parameters of OEE were calculated and OEE was determined for both excavators. The OEE values of excavator EX157 and EX158 were calculated to be $84 \%$ and $68 \%$ respectively. The OEE value of EX157 was found to be above to the benchmark value i.e. 
$77 \%$ (Elevli, 2010), and the value of OEE for EX158 was found to be far less than the benchmark value.

Table 1. Showing time losses and Overall Equipment Effectiveness estimation of excavators

\begin{tabular}{|c|c|c|c|c|c|}
\hline \multirow{2}{*}{$\begin{array}{l}\text { Type of } \\
\text { Losses }\end{array}$} & \multirow{2}{*}{ Item } & \multicolumn{2}{|c|}{ EX157 } & \multicolumn{2}{|c|}{ EX158 } \\
\hline & & Time (Hrs) & OEE Factors & Time (Hrs) & OEE Factors \\
\hline \multirow{6}{*}{ Availability } & Total Time & 617.85 & & 603.56 & \\
\hline & Idle Time & 17.54 & & 18.76 & \\
\hline & Truck Waiting Time & 3.66 & $89 \%$ & 4.10 & $79 \%$ \\
\hline & Unschedule Maintenance Time & 597.81 & & 1188.31 & \\
\hline & Setup and Adjustment Time & 173.73 & & 424.39 & \\
\hline & Propel Time & 46.03 & & 43.60 & \\
\hline \multirow[t]{2}{*}{ Performance } & Speed Loss & 16.86 & $99 \%$ & 17.13 & $90 \%$ \\
\hline & Job Condition Loss & 21.44 & & 20.49 & \\
\hline Quality & Quality Loss (Filling Factor) & $95 \%$ & $95 \%$ & $95 \%$ & $95 \%$ \\
\hline OEE $(\%)$ & & & $84 \%$ & & $68 \%$ \\
\hline
\end{tabular}

The time losses of the excavator unit EX157 resulting from the presence of unscheduled maintenance time i.e. of 597.81 hours, Setup and Adjustment Time of 173.73 hours, Propel Time of 46.03 hours, Job Condition Loss of 21.44 hours, Idle Time of 17.54 hours, Speed Loss of 16.86 hours, and Truck Waiting Time of $3.66 \%$.

The time losses on the excavator unit EX158 that the machine there are two sources of greatest losses i.e. the unscheduled maintenance time of 1188.31 hours and also caused from Setup and Adjustment Time of 424.39 hours. This causes component trouble to the Machine Frame, Structure, Body \& Cab.

\section{Discussion}

The source of the biggest losses on the excavator unit EX158 caused by unscheduled maintenance time i.e. of 1188.31 hours. The losses caused by the presence of trouble on Machine Frame, Structure, Body \& Cab component with downtime loses 719.41 hours or $60.9 \%$. So based on this condition, the losses on unscheduled maintenance time may imply that the problem lies in the Machine Frame, Structure, Body \& Cab. Therefore we need further analysis using a fishbone diagram to find out the root cause. 


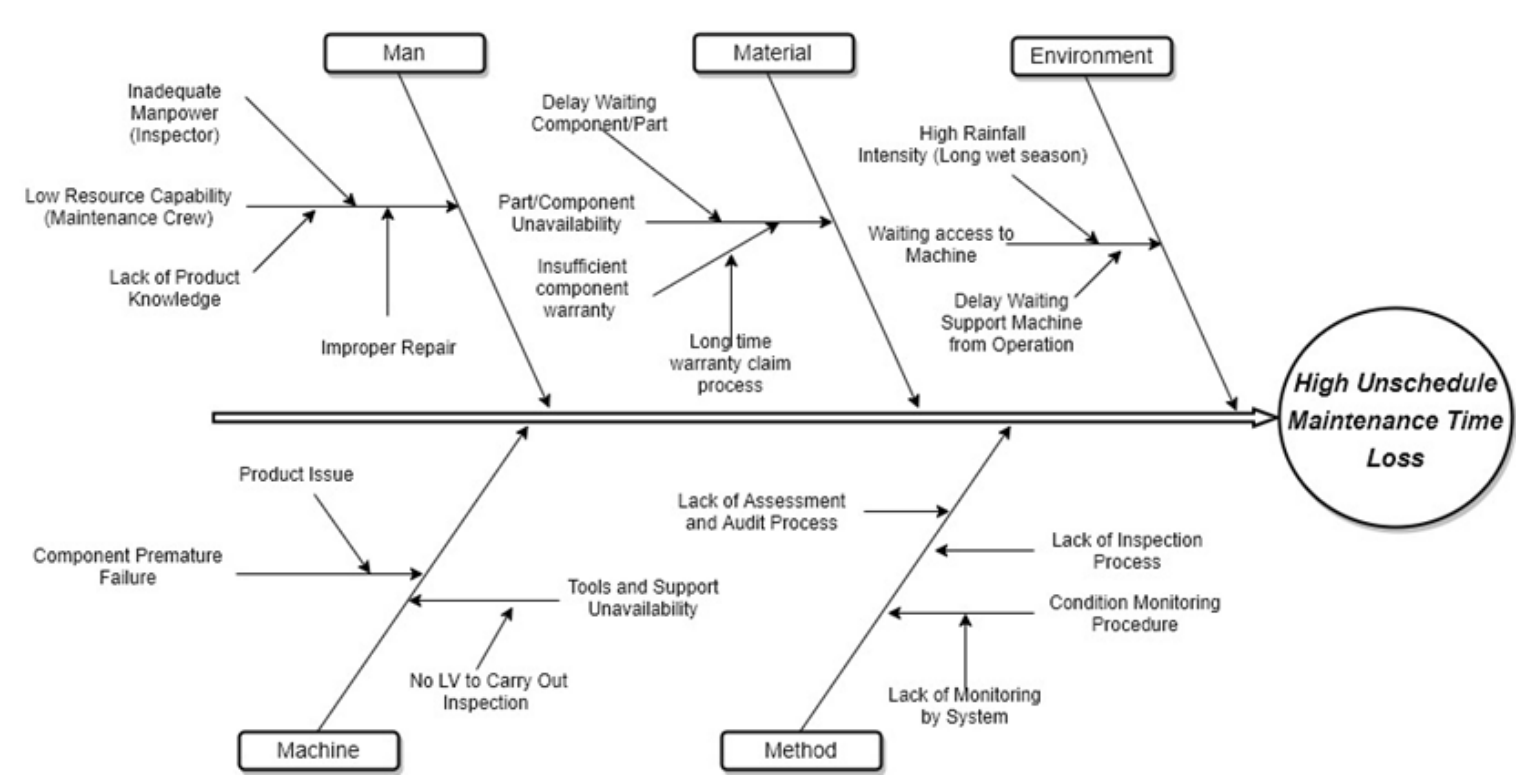

Figure 1: Trouble Machine Frame, Structure, Body \& Cab. Source: Time Losses calculation data $(\mathbf{2 0 1 8})$

The cause of the occurrence of trouble Machine Frame, Structure, Body \& Cab on the excavator unit of EX158: (a). The majority of mechanical compositions that handle excavator units are inexperienced, so they are less skilled in providing recommendations for solutions and follow-up actions. (b). Unavailability of parts / components stock in the warehouse due to the delivery process of parts / components that are too long. (c). The atmosphere in the workshop is too noisy and hot due to the area of the workshop area is not too large, and this also causes the mechanic to concentrate less on repairing the unit. (d). Lifetime unit is approaching due date which causes component unit damage. (e). Condition monitoring in the unit is not optimal due to lack of supervision from supervisors and lack of understanding of maintenance practice procedures.

Based on the analysis of the causes by using the diagram for further analysis is done using the $5 \mathrm{~W} 1 \mathrm{H}$ in order to get improvement the effectiveness of the excavator can be increased. The excavator unit EX158 has roots in trouble Machine Frame, Structure, Body \& Cab component.

\section{CONCLUSION AND SUGGESTION}

\section{Conclusion}

The OEE values of two excavators were calculated and were compared with the benchmark values. The OEE values of excavator EX157 and EX158 were calculated to be $84 \%$ and $68 \%$ respectively. The OEE value of EX157 was found to be above to the benchmark value i.e. $77 \%$ (Elevli, 2010), and the value of OEE for EX158 was found to be far less than the benchmark value. The low value of OEE on EX158 caused by unscheduled maintenance time losses amounting to 1188.3 hours. The high of time loss is influenced by trouble on Machine Frame, Structure, Body, and Cab components amounted to $60.9 \%$. 
The root causes of the losses derived from the availability of external mechanics, the competence of mechanics, the availability of spare parts, and the implementation of condition monitoring was not optimal. While remedial steps can be taken by giving technical training program for planners, mechanics and interpreters as maintenance practice methodology, and Expanding the workshop area on site with the aim of providing a sense of security and comfort for the maintenance team in doing repairs and maintenance of the unit.

\section{Suggestion}

The company should do OEE calculations on other fleets such as Dump Trucks, Dozers, Graders, and Cranes, in order to know the effectiveness of fleet units in the company and carry out continuous evaluations of suggested activities so that actual results are obtained as in this study. The company is expected to carry out program initiatives to increase the availability value in order to achieve the desired OEE value.

The company is expected to make a predictive maintenance project so that it can predict component failure early on and can reduce the amount of unscheduled maintenance time. The company is expected to encourage the maintenance department to carry out various improvements or initiatives in accordance with the concept of maintenance practice. So that the maintenance process is maintained properly and correctly.

\section{REFERENCES}

[1] Abdullah, Sarini. dan Taufik Edy Sutanto. (2015). Statistika Tanpa Stres. Transmedia. Jakarta.

[2] Akande, J., Lawal, A. I., \& Aladejare, A. E. (2013). "Optimization of the overall equipment efficiency (OEE) of loaders and rigid frame trucks in NAMDEB Southern Coastal Mine Stripping fleet, Namibia". Earth Science, 2(6), (2013), 158-16.

[3] Alam, Javed. Basant Kishore Mahanta. Nirajkumar Nawghade. (2018). "Comparative Performance Study of Mine Trucks by Overall Equipment Effectiveness (OEE)". International Research Journal of Engineering and Technology (IRJET). Vol. 5. p-ISSN: 2395-0072.

[4] Ansori, N. dan Mustajib, M. I. (2013). Sistem Perawatan Terpadu. Graha Ilmu. Yogyakarta.

[5] Arif Nuryono. (2017). “Analisis Efektifitas Kinerja Excavator Pada Aktifitas OB Removal Penambangan Batubara Menggunakan Metode OEE”. Journal Industrial Manufacturing. Vol. 3, No. 2, pp. 79-88.

[6] Besterfield. (2012). Total Quality Management Edisi Ketiga. Pearson Education. India.

[7] Dindarloo, S. R., Osanloo, M., \& Frimpong, S. (2015). "A stochastic simulation framework for truck and shovel selection and sizing in open pit mines". Journal of the Southern African Institute of Mining and Metallurgy. 115(3), (2015), 209-219.

[8] Elevli, S., Elevli, B. (2010). "Performance measurement of mining equipments by utilizing OEE”. Acta Montanistica Slovaca, 15(2), (2010), 95. 
[9] Haming, Murdifin dan Mahfud Nurnajamuddin. (2017). Manajemen Produksi Modern Operasi Manufaktur dan Jasa Edisi 2. Bumi Aksara. Jakarta Timur.

[10] Haryono, Lilik. Aries Susanty. (2017). "Penerapan Total Productive Maintenance Dengan Pendekatan Overall Equipment Effectiveness (OEE) Dan Penentuan Kebijakan Maintenance Pada Mesin Ring Frame Divisi Spinning I Di PT Pisma Putra Textile”. Industrial Engineering Online. Vol. 6, No. 4.

[11] Heizer, Jay. dan Barry Render. (2017). Manajemen Operasi Edisi 11. Salemba Empat. Jakarta.

[12] Hidayah, Nur Yulianti. Noor Ahmadi. (2017). "Analisis Pemeliharaan Mesin Blowmould dengan Metode RCM Di PT. CCAI “. Jurnal Optimasi Sistem Industri. Vol. 16, No. 2. ISSN: 2442-8795.

[13] Ihuezea, Christopher Chukwutoo. Chukwuebuka Martinjoe Dominic. (2017). "Maximizing Overall Equipment Effectiveness in a Food Processing Industry: A Case Study". Archives of Current Research International. ISSN: 2454-7077.

[14] Nakajima S. (1989). "Introduction to TPM". Productivity Press. Cambridge.

[15] Nallusamy, S. Gautam Majumdar. (2017). "Enhancement of Overall Equipment Effectiveness using Total Productive Maintenance in a Manufacturing Industry". International Journal of Performability Engineering. Vol. 13, No. 2, March 2017, pp.173188.

[16] Nusraningrum, Dewi. Zaenal Arifin (2018). "Analysis of Overall Equipment Effectiveness (OEE) on Engine Power Plant Performance". The 2018 International Conference of Organizational Innovation, KnE Social Sciences, pages 1270-1279. DOI 10.18502/kss.v3i10.3468.

[17] Nursubiyantoro, Eko. Puryani. Muhammad Isnaini Rozaq (2015). "Implementasi Total Productive Maintenance (TPM) Dalam Penerapan Overall Equipment Effectiveness (OEE)”. Jurnal Optimasi Sistem Industri.Vol. 9, No. 01. ISSN: 1693 - 2102.

[18] Nusraningrum, Dewi dan Zaenal Arifin. (2018). Overall Equipment Effectiveness (OEE) on Engine Power Plant Performance. Lambert Academic Publishing. Mauritius.

[19] Ramadhani, Delia Fitri. Harsono. Lisye Fitria (2014). "Usulan Peningkatan Efektivitas Mesin Cetak Manual Menggunakan Metode Overall Equipment Effectiveness (OEE)". Jurnal Online Institut Teknologi Nasional.Vol. 2, No. 04. ISSN: 2338 - 5081.

[20] Ranjan, Rajeev. Ajay Mishra. (2016). Evaluation and Optimization of Overall Equipment Effectiveness on a Pasting Machine in a Battery Manufacturing Industry, "International Journal of Performability Engineering". Vol. 12, No. 6. pp. 503-512.

[21] Ridwansyah, M. Dewi Nusraningrum. Ahmad H. Sutawijaya. (2019). “Analisis Overall Equipment Effectiveness Untuk Mengendalikan Six Big Losses Pada Mesin Pembuatan Nugget”. Jurnal Ilmiah Manajemen \& Bisnis. Vol. 3, No. 1.

[22] Saha, Saji.b Sadi Mohammad Akash. Tarun Kumer Biswas. (2017). "Improving OEE of a Garment Factory by Implementing TPM Approach". International Conference on Mechanical, Industrial and Materials Engineering 2017 (ICMIME2017). ID: IE-268. 
[23] Saiful, Amrin Rapi. Olyvia Novawanda. (2014). "Pengukuran Kinerja Mesin Defekator I Dengan Menggunakan Metode Overall Equipment Effectiveness". Journal of Engineering and Management in Industrial System. Vol. 2, No. 2.

[14] Sugiyono. 2013. Metode Penelitian Kuantitatif, Kualitatif, dan R \& D. Alfabeta Bandung. Bandung.

[15] Suliantoro, Hery. Novie Susanto. Heru Prastawa. Iyain Sihombing. (2017). Penerapan Metode Overall Equipment Effectiveness (OEE) dan Fault Tree Analysis (FTA) untuk mengukur efektifitas Mesin. "Jurnal Teknik Industri”. Vol. 12, No. 2.

[16] Sumantri, Mohamad Syarif. 2015. Strategi Pembelajaran: Teori dan Praktik di Tingkat Pendidikan Dasar. Raja Grafindo Persada. Jakarta.

[17] Tambang, Admin. (2019). Produksi Batubara Naik: Umur Batubara Masih Panjang. https://duniatambang.co.id/Berita/read/88. (Diakses tanggal 2 Agustus 2019, Jam 22:30).

[18] Tobe, Yermia Adi. Denny Widhiyanuriyawan. Lilis Yuliati. (2017). "The Integration of Overall Equipment Effectiveness (OEE) Method and Lean Manufacturing Concept to Improve Production Performance (Case Study: Fertilizer Producer)". Journal of Engineering and Management in Industrial System. Vol. 5, No. 2. P-ISSN 2338-3925. 